\title{
Lumen
}

Selected Proceedings from the Canadian Society for Eighteenth-Century Studies

\section{The Clubbable Bard: Sentimental Scottish Nationalism and Robert Burns}

\section{Corey Andrews}

Volume 21, 2002

URI : https://id.erudit.org/iderudit/1012270ar

DOI : https://doi.org/10.7202/1012270ar

Aller au sommaire du numéro

Éditeur(s)

Canadian Society for Eighteenth-Century Studies / Société canadienne d'étude du dix-huitième siècle

ISSN

1209-3696 (imprimé)

1927-8284 (numérique)

Découvrir la revue

Citer cet article

Andrews, C. (2002). The Clubbable Bard: Sentimental Scottish Nationalism and Robert Burns. Lumen, 21, 105-130. https://doi.org/10.7202/1012270ar

Copyright (C Canadian Society for Eighteenth-Century Studies / Sociéte canadienne d'étude du dix-huitième siècle, 2002
Ce document est protégé par la loi sur le droit d'auteur. L'utilisation des services d'Érudit (y compris la reproduction) est assujettie à sa politique d'utilisation que vous pouvez consulter en ligne.

https://apropos.erudit.org/fr/usagers/politique-dutilisation/ 


\section{The Clubbable Bard: Sentimental Scottish Nationalism and Robert Burns}

As universally known as the life of Robert Burns appears to be, the story of his involvement in numerous clubs and societies has remained surprisingly perfunctory and limited. Even in James Mackay's voluminous biography Robert Burns, one does not find very much information about Burns's activity in such groups as the Tarbolton Bachelors Club, the Court of Equity, and the Crochallan Fencibles, to name a few. However, the importance of such groups to Burns himself is difficult to miss. He formed the Tarbolton Bachelors Club in 1780 for the purpose of self-improvement, and the posthumous 1799 edition of The Merry Muses of Caledonia was presumably 'selected for the use of the Crochallan Fencibles' (Burns, Merry Muses 2). Any casual reader of Burns can attest to his genial sociability, an element of his character that he constantly satisfied during his life through joining or forming clubs of his own making. He was, to borrow a phrase, an eminently 'clubbable' poet.

Burns maintained his popular appeal in his club poetry and activity by adapting and transforming his persona from that of the 'heaventaught ploughman' to the bard, a poet who would speak for the nation through himself. Like many eighteenth-century Scots, however, Burns was a paradoxical figure, at one moment espousing strong anti-Union rhetoric, at another endorsing the values of being British. ${ }^{1}$ However, if such duality is taken as a given attribute of eighteenth-century British identity, seen not as an essential character flaw of Scots but as a fact of life for the English and Scottish alike as Britons, one can discern in

1 As Robert Crawford remarks in the section entitled 'British Burns' of his book Devolving English Literature (Edinburgh: Edinburgh University Press, 2000), 'Burns was bicultural [...]. He drew on, and negotiated between, the Scots folk-culture of his family and background, and the officially dominant Anglicized culture of his formal education and most of the metropolitan values with which he came into contact' (88-89). 
Burns's life and works an especially vivid negotiation of this experience. More strongly than club poets before him, Burns tapped into the structures of feeling that shaped his culture and attempted to make sense of that culture by using and adapting the sentiment behind those structures. If he was unable to resolve the experience of paradox in his own life, he was at least able to redirect it and turn it into an expression of national sentiment that generations of Scots after would still find valuable.

Despite its obscurity in his poetic oeuvre, Burns's club poetry acted as a significant part of this nationalist project by representing the poet's own bardic character as a source for national unification. Like much of his other verse, Burns's club poems open themselves to universal concerns, asserting that 'a man's a man for a' that' as well as 'a man's a Scottish club man for a' that.' It is undeniable that such gestures have made (and continue to make) Burns's poetry genuinely popular, from his time to ours. It is one of the chief qualities of his verse that contributes to his appeal as not only a national but a world poet. ${ }^{2}$ In his club verse, however, Burns demonstrated a striking awareness of his role as a national bard; through self-representation, he offered his own popular character as a bard to members and citizens alike as an index for their shared national memory. ${ }^{3}$

A large part of Burns's continuing appeal to Scottish and international readers resides in his sentimental quality, his rustic appearance and apparently disingenuous and 'native' intellect conspiring to make him a diamond in the Ayrshire rough. Though early critics like Henry Mac-

2 Thomas Crawford persuasively argues at the end of his influential book Burns: A Study of the Poems and Songs (Edinburgh: Canongate, 1960) that Burns should be considered a 'world poet' due to the 'increasing concentration and universalisation of his central interests and positive values' (337). For this reason, Crawford claims that Burns 'appears as a regionalist only up to a point. In his finest works he is a writer who belongs not to Scotland only, but to the whole world' (347). In many points I agree with Crawford's general argument about Burns's 'universalism,' but I will focus more particularly on how Burns employs a universalist strategy in his club poetry as a means of national unification. In this respect, my argument departs pronouncedly from Crawford's.

3 Robert Crawford notes in Devolving English Literature that Burns's adoption of the bardic persona was a deliberate, conscious decision on the poet's part: 'After reviews of the Kilmarnock edition of his Poems in late 1786, the literary world began to accord Burns star status; he responded by referring to himself as "my Bardship" [...]. Gray's The Bard and Macpherson's Ossian (much admired by Burns) had furthered an enthusiasm for ancient, dignified, vatic bards' (92). 
kenzie were largely responsible for inventing and promoting this persona, Burns also clearly thought of himself (or at least part of himself) as a 'heaven taught ploughman.' Such self-representations not only reveal that Burns was canny when it came to self-promotion, but that he understood that his rustic persona had a use value and a potential unifying function. If Scots could not agree about the country's political direction, they could at least concede that an undeniably talented 'native' poet from Ayrshire could represent a positive value for Scotland.

In a sense, Burns's rise from a difficult and by all accounts dreary life as a farmer to overnight literary fame in Britain and abroad is the 'lad o' pairts' narrative a hundred years early. Though the literati may have had doubts about Burns's value almost immediately after they let him in their homes, his very existence seemed to confirm the belief that hard work, when combined with native intelligence, could overcome any obstacle to success. This cultural notion, identified strongly in Scotland with the 'Kailyard School' of the late nineteenth century, certainly could be (and was) translated into a nationalist perspective, with figures like Burns seen to affirm distinctly 'Scottish' qualities of independence and self-reliance in the eyes of many Scots. ${ }^{4}$

Burns quickly discovered though that the persona of the heaventaught ploughman' could be very restrictive of the character of both his life and verse. Assuming the different poetic role of the bard did not have to necessitate a certain 'bardic' behavior, for inasmuch as Burns was recognized as a bard on account of his poetry, he was a bard. In other words, bardship is more a state of being that one 'deserves' than a process or an action. Carol McGuirk provides a clear description of the intertwining of personal and national that go into the making of a bard: 'broadly defined, a bard is a poet whose insights convey a national perspective and for whom self-expression simultaneously involves cultural definition' (106). The bard's self-expression is intimately linked with his understanding of the past, particularly how he sympathetically connects with the spirit of the many nameless bards who have gone before him. In this way the bard channels a national voice through the medium of his poetry, simultaneously confirming his own personal bard status while expressing his nation's culture in verse.

4 The 'lad o' pairts' was a narrative trope in the work of late nineteenth-century Scottish novelists like J.M. Barrie, Ian McLaren, and S.R. Crockett; it typically represented the material prosperity of a young provincial Scot brought about by his innate talents and hard work. 
Katie Trumpener explains how the poetic activity of such bards had a strong contemporary political component as well as a pronounced sense of national history: 'Scottish, Welsh, and Irish nationalists conceive a new national literary history under the sign of the bard, a figure who represents the resistance of vernacular oral traditions to the historical pressures of English imperialism and whose performance brings the voices of the past into sites of the present' (33). Trumpener claims that 'as a figure both of the traditional aristocratic culture that preceded English occupation and of continued national resistance to that occupation, the bard symbolizes the central role of literature in defining national identity' (xii). Few poets in the eighteenth and nineteenth centuries in Britain can compete with the influence of Burns in this regard; his invaluable collections of Scottish songs for both James Johnson and George Thomson, along with his own Scots poetry, represent a determined 'continued national resistance' to the pressures of an assimilationist British/English culture. ${ }^{5}$

Burns's use of iconic Scottish figures like Wallace and Bruce was a key factor in the success of his verse in defining a Scottish national identity that Scots of differing political persuasions could find at least sentimentally satisfying. ${ }^{6}$ Unlike other eighteenth-century poets who adopted a 'bardic' persona in their works such as Thomas Gray, Burns could lay a claim for the authenticity of his role as a bard; as McGuirk remarks, 'the major difference between Burns and other eighteenth-century bards is that he was really from the Scottish culture his bardic personae speak for' (106). Burns understood that the figure of the bard was more powerful and durable than Gray had imagined in his exercise in bardic nationalism, 'The Bard,' where prophetic national utterance is channeled through a suicidal bard. For Burns, the voice of ancient Scottish bards could be his voice, their nation laying not in the remote past but in the here and now. No death was needed to register injustice or extol the merits of national heroes or bards; Burns simply had to keep their work alive through his own.

5 It is likewise important to point out in this regard that Burns thought of himself emphatically as a 'Scotch Bard,' which, as Crawford remarks in Devolving English Literature, 'acknowledges not only the country, but the language of the author of Poems, Chiefly in the Scottish Dialect' (95). Burns's insistence on his 'Scotch' qualities as a bard forms a central part of his resistance to the assimilationist elements of British culture at the time.

6 Consider, for instance, the canonical status of 'Scots Wha Hae' in collections of Burns's verse from the nineteenth century and onward. 
One of the first steps that Burns would have to take towards this end was to gain an audience that would take his bardic efforts seriously. In November 1780, he founded the Tarbolton Bachelors Club, formed for the simple purpose of helping members, in their own words, 'to become wiser and better.' The chief means of achieving this end was through the debate of such topics as 'whether is a young man likeliest to be happy, who has got a good education, and his mind well-informed, or he who has just the education and information of those around him?' (Burns, Works 29). As in many Burns clubs then and now, the poet was emphatically at the center of the Tarbolton Bachelors Club, not only founding it but acting as its first president. The club, which met irregularly from late 1780 to 1784, had a significant role in the development of Burns's personality and character as well as his debating skills. His education in sentimental culture began in earnest during this period, for his experiences in the club allowed him to investigate the discourse of sentimentality through argument and discussion.

It was through the experience of debate and friendship in the Bachelors Club - both of which emphasized a serious engagement with ideas and beliefs - that Burns developed the 'overly emphatic self-consciousness' (McGuirk 91) that is a distinctive element of his sentimentalism. David Daiches has persuasively argued that the Tarbolton Bachelors Club should be seen as 'clear evidence of [Burns's] need and use of an audience' (58). Daiches writes that 'what encouraged [Burns] most was his audience. He now had friends and companions to whom he could recite his verses and whose applause fired his ambition' (58). The club acted as a vehicle for the performance of the poet, whose skill in argument and versifying was the central object of attention. As a practice ground, the club helped Burns to refine and develop his ideas and early verse by allowing for his friends not only to applaud but also challenge him in debate.

The best-known aspect of the Bachelors Club's history is its ten rules for membership, of which the tenth rule has been frequently cited; this rule states that the candidate must have 'a frank, honest, open heart; above anything dirty or mean; and must be a professed lover of one or more of the female sex' (Burns, Works 250). The last quality, the subject of countless sly critical asides, may have been the result of juvenile humor, but it nonetheless firmly situates the potential member in a sentimental context. Like Sterne's admiring Yorick in Sentimental Journey, the Tarbolton Bachelor must allow his honest, open heart to be moved frequently by the female sex, whether or not he finds any of them serious prospects for romance. It is the indoctrination of Yorick's credo of love - ' [I have] been in love with one princess or another almost all my life, and I hope I shall go on so, till I die, being firmly persuaded, that 
if ever I do a mean action, it must be in some interval betwixt one passion and another' (Sterne 34).

Certainly Burns's later encounters with numerous women throughout his life reflect Yorick's philosophy of love, and it cannot be said that his sentimental education served him very well in this regard. Burns's own brother Gilbert remarked that 'as Yorick's affections flowed out toward Madam de L - at the remise door, while the eternal vows of Eliza were upon him, so Robert was frequently encountering other attractions, which formed so many underplots in the drama of his love' (Burns, Works 20-21). Like his hero Yorick, Burns's typically elaborate overtures to often expressly unavailable women (Agnes McLehose most famously) frequently degenerated into frustrating and comical exercises in sentimental posturing for both parties involved. ${ }^{7}$ Burns's awareness of how sentimental behavior invited ridicule led him to include another restriction in the tenth rule detailing the ideal Tarbolton Bachelor, underscoring his anxious concern about the censure of outsiders - ' No haughty, self-conceited person, who looks upon himself as superior to the rest of the Club, and especially no mean-spirited, worldly mortal, whose only will is to heap up money, shall upon any pretence whatever be admitted' (Burns, Works 250).

Along with protecting the integrity of the Tarbolton Bachelor, this rule seeks to elevate him above the 'mean-spirited, worldly mortal[s]' who would scoff at the club's sentimental dictums on their way to the bank, so to speak. The tenth rule emphatically sets the improving purpose of the club - sentimental education through debate, making members 'wiser,' 'better,' and more passionate - over and above the work of other organizations designed to 'improve' members through assimilation of English culture for their material benefit. In 1780, the year of the club's founding, Scotland was still losing many of its talented males to its southern neighbour. Despite all-round resentment throughout Britain at the professional and material success of such emigrants, London still opened its doors to the many Scots seeking entrance, and English society still demanded that these would-be Britons lose their rough-edged rusticity through the practice of polite manners and polite speech. ${ }^{8}$ As improving

7 There is no clearer example of Burns's sentimental extremes than in the 'Sylvander/Clarinda' correspondence. Mackay remarks that 'between December [1787] and mid-March [1788] at least eighty letters (forty-two from Robert) passed between them; at the height of this epistolary romance, as many as two letters in each direction passed between them on some days' (373).

8 In Britons: Forging the Nation, 1707-1837 (New Haven: Yale University Press, 1992), 
clubs had done earlier in the century, so debating societies performed a similar function for the Scot eager to cash in on his Britishness; in a sense, debate in such societies was nothing more than a parlor room ploy for personal advancement. Boswell, for one, was an enthusiastic supporter of such societies and attended them in London and Scotland. ${ }^{9}$

For Burns, however, a debate society was meant to complement and enhance an already sound character, not alter an 'incorrect' one. The tenth club rule makes this clear: 'the proper person for this Society is a cheerful, honest-hearted lad; who, if he has a friend that is true, and a mistress that is kind, and as much wealth as genteely to make both ends meet - is just as happy as this world can make him' (Burns, Works 250). Many topics for debate in the Tarbolton Bachelors Club often reflect this concern for the improvement of fundamentally solid, rather than flawed characters, while others seem like elements of a roman à clef of Burns's early life. For instance, consider the following topic:

Suppose a young man, bred a farmer, but without any fortune, has it in his power to marry either of two women, the one a girl of large fortune, but neither handsome in person, nor agreeable in conversation, but who can manage the household affairs of a farm well enough; the other of them a girl every way agreeable, in person, conversation, and behavior, but without any fortune: which one shall he choose? (Burns, Works 29)

Such is the stuff that both Burns's legend and sentimental novels are made of. Although the topic above evokes romantic conflicts typical of Burns ${ }_{10}^{10}$ more significantly it begins to establish the contours of a recog-

Linda Colley states that as a part of the 'forcible integration' of Scots into British politics and commerce, they were allowed 'to compete for advancement in the state on a wider scale and on more favourable terms than ever before' (120). English hostility against the competing Scots was, in Colley's view, 'testimony to the fact that the barriers between England and Scotland were coming down, savage proof that Scots were acquiring power and influence within Great Britain to a degree previously unknown' (121).

9 Boswell was made an honorary member of the Pantheon Society in Edinburgh in 1775 and attended off and on for roughly ten years. Davis McElroy notes that one reason Boswell recorded for his attendance in 1779 was 'to get some reputation among people of various ranks and professions who would spread it' (Scotland's Age of Improvement: A Survey of Eighteenth-Century Literary Clubs and Societies [Pullman, WA]: Washington State UP, 1969: 93).

10 It is singularly unsurprising to learn of Burns's support for the agreeable, fortuneless woman in this debate. 
nizable character that Burns was beginning to develop in his club verse. This character, as I have tried to illustrate, was emphatically sentimental, a 'cheerful, honest-hearted lad' who valued friendship and romance over the desire to 'heap up money.'

Along with contributing to his construction of a national character, Burns's participation in a club designed (in theory at least) as a forum for impartial debate also enabled him to criticize points of argument from varying perspectives. A potential for self-assessment is virtually guaranteed with this approach, especially when applied by an intelligent, already self-conscious person. Learning the language and strategies of argument in this manner provided Burns with the rhetorical resources he needed not only to write good poetry, but also to create points of identification with diverse audiences in his club verse. He often did this in his later club poetry often by means of a sentimental figure such as a drinking mate, a soldier, or a bard, ${ }^{11}$ represented broadly enough to appeal to differing readers united principally by nationality. The lessons of Burns's sentimental education are most evident in such procedures, where he displays a sharp understanding of rhetorical topoi.

The early direction of Burns's nationalism is evidenced in the kind of Scottish character elaborated in the Tarbolton Bachelors Club rules and debate topics. As Burns continued writing for clubs, however, the Scottish character he represented in his verse became increasingly amorous and explicit. In fact, one of the great virtues of Burns's sentimentalism is its frankness about the sexual desire at its core. Though Burns relished the bashfulness of the 'Man of Feeling' which Henry Mackenzie had claimed was 'a consciousness, which the most delicate feelings produce, and the most extensive knowledge cannot always remove' (9), Burns was at the same time highly contemptuous of sentimental discourse that tried to evade the issue of sexuality. ${ }^{12}$ Making candid assertions of his own sexuality in his writings not only affected Burns personally by providing ammunition for the 'unco guid' who hounded him throughout his life,

11 Burns used each of these figures for group unification in different sections of one of his best-known poems, 'Love and Liberty.'

12 For instance, in a letter to Dr. John Moore (no. 437) of February 28, 1791, Burns derided one of the century's most notable sentimental novelists in no uncertain terms: '[Richardson's] Dramatis personae are beings of some other world; \& however they may captivate the unexperienced, romantic fancy of a boy or a girl, they will ever, in proportion as we have made human nature our study, disgust our riper minds' (Letters 2:74). 
but they also contributed to the notoriety that continues to shadow his reputation.

One of the first groups in which Burns broadened his conception of character to include sexuality was the 'Court of Equity,' a small club of four young men formed in Mossgiel in 1785. Its members comprised of James Smith, John Richmond, William Hunter, and Burns, and like the Tarbolton Bachelors Club, it was intended for young unmarried fellows. However, quite unlike the former club, the Court of Equity was an expressly 'impolite' group, meeting to discuss and pronounce on each other's sexual activities. Catherine Carswell describes the club in vivid language, noting that in Mossgiel society, Burns

was an acknowledged leader in impudent immorality. Instead of conducting fellow-bachelors, as at Tarbolton, along the path of mutual improvement [...] he had formed a gang which called itself the "Rebel Four" and of which fornication was the principal and avowed interest (139).

The 'Rebel Four' (simply another name for the Court of Equity) in fact required that each member be not only a bachelor 'in love with one or more' as in the Tarbolton Bachelors Club but that he 'must have given proof of his fruitfulness' (Carswell 139).

The club's method of organization and style of meeting caricatured the formal, rule-oriented Tarbolton Bachelors Club as well as the Mauchline Kirk Session, before which Burns and his compatriots had unpleasantly sat. Mackay gives a brief portrait of the club's activity:

Robert was chairman of course, Smith the fiscal (public prosecutor), Richmond the clerk of the court and Hunter the messenger at arms. This mock court proceeded to examine some of the scandals of Mauchline and bring to book the offenders against the moral code who had so far managed by various ploys to evade the penalty of their transgressions (177).

In its sentencing of 'offenders against the moral code,' however, the Court of Equity was not concerned with enforcing the moral code but rather in exposing the hypocrisy of those who routinely broke it themselves but upheld its strictures against others.

Though the Court of Equity did not remain active very long, disbanding in the spring of 1786, its purpose and actions are represented at some length in Burns's club poem, 'Libel Summons' (no. 109). ${ }^{13}$ The poem, long considered too vulgar for publication, was first printed in 1930 in the appendices of Carswell's Life of Robert Burns, an act for which she met with severe criticism from critics and admirers of Burns (Mackay 177). As the Kirk had been pursuant on Burns and the other three offenders 
against the moral code in the club, so they sought in 'Libel Summons' to prosecute those who did not submit to the Court of Equity's disciplinary code that relied 'on a principle not of chastity but of promiscuity, and condemn[ed] not fornication but cowardice in confessing it' (Burns, Poems and Songs 3:1186). The work of the 'Court of Equity' was to enforce a code of honor by which all fornicators should be bound, particularly in their responsibility for the care of illegitimate offspring. This was a real concern for club members, one for which they were particularly suited to sit in judgement. ${ }^{14}$

Through the course of the poem, Burns expounds on the idea of 'the Fornicator's honor' in order to establish the need for its equal enforcement in the community. Though the judges' own personal feelings of unfair enforcement (Burns, Richmond, and Smith had all appeared before the Kirk session) contributed to their stance, the concept of an equitable code of behavior must have also appealed strongly to Burns and have extended beyond the province of his own private grievances. As in his other club poetry, Burns attempted in 'Libel Summons' to create a character type with which members could identify, here focused on both the pleasures and responsibilities of fornication. Even if the court's own judges could not meet the standards demanded by the 'Fornicator's honor,' they owned up to their misdeeds and in so doing, validated the code of behavior by which men ought to conduct themselves. ${ }^{15}$

Unlike the Kirk session which punished the existence of the sexual drive itself in offenders before its court, the Court of Equity distinguished between sexual pleasure and sexual conduct, finding the latter in need of enforcement if the consequences of the first were not honorably met. In other words, it was no crime to be a fornicator pure and

13 All citations of Burns's works refer to James Kinsley's authoritative edition, The Poems and Songs of Robert Burns (3 vols. Oxford: Clarendon, 1968).

14 Burns, John Richmond, and James Smith successfully met the criterion for membership at the time by siring illegitimate offspring, and William Hunter apparently did as well (though very little information exists about him beyond the known fact that he was a shoemaker).

15 For instance, Burns chastised Richmond for his abandonment of Jenny Surgeoner in a letter (no. 4) of Sept. 1, 1786, an act that anticipates the judgements to be passed down by the poetical Court: 'You are acting very wrong, My friend; her happiness or misery is bound up in your affection or unkindness. - Poor girl! [...] Richmond, I know you to be a man of honour, but this conduct of yours to a poor girl who distractedly loves you, and whom you have ruined [...] forgive me, my friend, when I say it is highly inconsistent with that manly INTEGRITY that I know your bosom glows with' (Letters 1:50). 
simple in the Court of Equity, but charges would be pressed if the fornicator acted as if only his own sexual pleasure were the whole of fornication. To decide the fate of these dishonorable fornicators, Burns's speaker listed the qualifications and duties of each judge in the Court of Equity. Burns himself served as the chief justice because he had a 'DUPLICATE pretension' (Burns, Poems and Songs 1:256-62, 32) to the title in having fathered two illegitimate children, while Smith served as the fiscal, Richmond the clerk, and Hunter the messenger at arms.

On the court's docket in 'Libel Summons' is a trial of two defendants, 'Coachman DOW and Clockie BROWN' (55), who have 'been at wark at HOUGHMAGANDIE' (58) and now stand accused of denying their responsibilities: 'And now when facts are come to light,/The matter ye deny outright' (59-60). The court's resentment about the defendants' breach of the 'Fornicator's honor' is expressed in the following lines: 'reluctantly we PUNISH,/An' rather, mildly would admonish:/Since Better PUNISHMENT prevented,/Than OBSTINACY sair repented. -' (99-102). The court reasons that if the men's denial of their behavior is motivated by shame of having fornicated, then they shouldn't have fornicated in the first place. Such duplicitous behavior threatens to ruin the criterion of character that should govern relations between men. The court alludes to the case of 'Godly Bryan,' another denying fornicator, and asks'When such as he put to their han',/ What man on CHARACTER need stan'?' (122-23). To prevent the further erosion of 'CHARACTER,' the speaker exhorts the men to

\section{lift up your brow,}

And, like yoursel, the TRUTH avow;

Erect a dauntless face upon it,

An' say, "I am the man has done it;

"I SANDIE DOW GAT MEG WI' WEAN,

"An's fit to do as much again." (124-129)

For the Court of Equity, such a confession of fornication does not entail shame and punishment as it would in the Kirk session but instead acts as an assertion of sexual pleasure, spoken with a 'dauntless face' and affirmed by the support of a quorum of fornicators.

As a club poem, whether it documents an actual or imagined meeting, 'Libel Summons' is a remarkable production for the clarity and novelty of its unifying approach. By assuming juridical personae and employing legal jargon, the club satirizes the arcane and intrusive quality of the powerful Kirk session in an obvious manner. However, 'Libel Summons' departs from one-dimensional satire in the presentation of the 'cases' it is calling to trial. Burns and his cohorts in the club obviously enjoyed 
spoofing the Kirk session, more so because they were each well-versed in its procedures, but the poem registers as much moral outrage as a typical case judged by the session. Lying fornicators like Dow and Brown elicit sharp rebukes from the court because the defendants' bald-faced denial of the truth of their fornication brings discredit on fornicators everywhere, threatening to ruin their 'character.' This logic, though unconventional and unacceptable to the majority of the community in Mossgiel, makes sense within the confines of the club. In the mind of the court, it should make sense to all fornicators at all times and in all places.

Due to Burns's supposed proclivity for excess in all forms, it has become altogether too easy for critics to dismiss verse like 'Libel Summons' as simply bawdy and occasional. Such conclusions confirm the stereotype of Burns as an amorous rhymester, wandering about the countryside armed with only his libido and his pen. But club poems like 'Libel Summons' demonstrate that Burns wrote such verse for a reason: he wanted to explain and interpret sociability by constructing a character type with which members could identify. The experiences of the members of the Court of Equity clearly did not correspond with the social and cultural expectations of the Kirk, the primary ideological center of the Scottish village, but Burns articulated the club's difference in verse that sought to represent their own beliefs and activities as natural and normal.

Burns found a sympathetic audience for such ideas in the Crochallan Fencibles, an Edinburgh club that he joined after the 1787 Edinburgh edition had guaranteed that he would not go unnoticed in the Scottish capital from 1787-88. In his accompanying essay to the recent facsimile of The Merry Muses of Caledonia, G. Ross Roy describes the Fencibles as a group 'founded by William Smellie, who printed the Edinburgh edition of Burns's poems [...]. Burns wrote a poem about Smellie, and referred to him in a letter as an "old Veteran in Genius, Wit and B[aw]dry"' (viii). ${ }^{16}$ As he had for the Court of Equity, Burns focused primarily on sexual pleasure as a key element of the group's self-definition in his club poetry for the Fencibles, a more relaxed, celebratory, and convivial club than any he had yet visited at the time in Edinburgh. More emphatically than in 'Libel Summons,' Burns mobilized exaggeratedly sexual repre-

16 McElroy adds that the Crochallan Fencibles were formed circa 1778 as a response to the threat of a potential invasion during the American Revolution; 'fencibles' referred to the groups of volunteers throughout the country at the time who formed impromptu militias. 'Crochallan' refers to an old Gaelic song, 'Cro chalien' (Colin's cattle), that was sung by one of the members during club meetings (McElroy 150). 
sentations of masculinity as a means of unifying the Fencibles. These representations were not directed towards the equalization of members but rather for the promotion of their own sense of difference from the club's outsiders, both men and women.

Several Fencibles were quite prominent in Edinburgh society for their rank or profession; the club consisted of three Lords, five Writers to the Signet, an advocate, a judge, a captain, and a doctor, among others. Despite the number of titled Fencibles, however, the group was not considered by the Edinburgh gentry and literati to be particularly elite or select. Mackay explains that

when Dugald Stewart spoke of Robert keeping "not very select society" he meant people like William Dunbar, William Smellie, William Nicol and Alexander Cunningham, gentlemen who were not of the rarefied stratum as himself and the literati, but who nonetheless were eminently respectable in their own right (291).

The Crochallan Fencibles were primarily noted for their conviviality, which was perhaps one reason for the disdain of more prominent Scots like Stewart. A key part of initiation into the club evidently entailed rather draconian hazing which Burns described as being 'thrashed' beyond all his experience (Mackay 289).

The excessive conviviality of this society has been long accused by Burns's critics of having encouraged and exacerbated the poet's alcoholic tendencies, hastening his premature death. ${ }^{17}$ Davis McElroy's comment is typical; he claims that whoever introduced Burns to the Fencibles

did Burns both a service and a disservice: a large part of the esprit de corps of the Crochallans was spirits and Burns had a dangerous thirst. Legend has it that when Burns lay dying he lamented: "Oh the Edinburgh gentry. Had it not been for them I had a constitution that would have stood anything" (150).

However, it is important to examine Burns's activity and verse for the Fencibles more closely in order to determine to what extent such admittedly apocryphal statements signify his actual involvement in convivial excess or its representation in verse. As Mackay rightly points out, unverified references to 'all-night sessions in the taverns off the High

17 However, most current biographers and critics of Burns agree that the poet's early death was not the result of his drinking but rather of bacterial endocarditis. 
Street doubtless helped to create the canard of Burns's hard drinking' $(291){ }^{18}$

Undeniably, Burns felt strongly about the Fencibles due to the amount of club verse that he produced for them, which outnumbers the verse he wrote for other clubs and groups. However, it is quite interesting to find that the poetry and songs he wrote for the Fencibles are not predominantly convivial as one might expect. Instead, Burns focused on writing or collecting specimens of bawdy verses that were published after his death as The Merry Muses of Caledonia (1799), ${ }_{19}$ with the subtitle 'Selected for the Use of the Crochallan Fencibles.' Though he wrote poems that honored club members (of which 'Rattlin' Roarin Willie' [no. 216], dedicated to fellow Fencible William Dunbar, is a well-known example), clearly the length and explicit nature of the Merry Muses demonstrates that the concerns and aims expressed in 'Libel Summons' had not been forgotten after his move to Edinburgh. In fact, the representation of sexual behavior seen in the earlier poem became much more detailed and explicit in the Merry Muses, in order to be literally 'used' by the Fencibles for self-identification as club members.

By far the most contentious element of the Burns canon, The Merry Muses of Caledonia has been the subject of innumerable critical tirades, not the least of which concerns Burns's actual participation before his death in its execution, design, and production. ${ }^{20}$ In fact, Burns's name appears nowhere in the collection, and there is no evidence to prove that

18 In Bacchus in Romantic England: Writers and Drink, 1780-1830 (London: Macmillan, 1999), Anya Taylor notes that 'later biographers have tried to deny Burns's drunkenness and thus to restore his simple, pure reputation. Ignoring the many poems praising drink and drinkers in the first editions of the poetry [...] they censor from letters and memoirs evidence of Burns's wild behavior. As Alan Bold quips, Currie's "infamous judgement on Burns [...] so outraged modern Burns scholars that they will have gone to the other extreme and made the often-plastered saint an almost teetotalitarian figure"' (34). That the debate over Burns's drinking is still being waged in extremes - either 'teetotalitarian' or 'often-plastered saint' - seems entirely symptomatic to me of the passionate regard many still hold for Burns. For my part, I feel that Burns probably enjoyed drinking and likely overindulged on occasion, but I don't believe that one can make judgements on the extent of his excess based solely on his literary representations of drunkenness (which fit into a tradition of Anacreontics, drinking songs, and so on).

19 I refer here to the 1799 facsimile edition described by Roy on xvii-xix.

20 Roy aptly remarks that 'Burns is best known as the National Bard of Scotland; his birthday is celebrated in hundreds of annual gatherings around the globe. Robert Burns also wrote bawdry, although there were persistent attempts to conceal this fact' (iii). See also Roy ix-xviii for a useful history of the Merry Muses. 
he devised either its title or epigraph: 'Say, Puritan, can it be wrong,/To dress plain truth in witty song?/What honest Nature says, we should do;/What every lady does, - or would do' (Burns, Merry Muses 2). ${ }^{21}$ Burns never referred in his correspondence to a collection entitled the Merry Muses, but editors have pointed to two letters (one from December 1789 and the other from March 1792) that discuss a collection of 'baudy' that may have been the source of the Merry Muses. The first letter (no. 378), addressed to Provost Robert Maxwell and dated December 20, 1789 , announces Burns's intention to write 'baudy' for Maxwell's pleasure in no uncertain terms:

I shall betake myself to a subject ever fertile of themes, a Subject, the turtle-feast of the Sons of Satan, and the delicious, secret Sugar-plumb of the Babes of Grace; a Subject, sparkling with all the jewels that Wit can find in the mines of Genius, and pregnant with all the stores of Learning, from Moses \& Confucius to Franklin \& Priestly - in short, may it please Your Lordship, I intend to write BAUDY! (Letters 1:462).

Burns's second letter about the subject of a secret collection of bawdry confirms his interest in this 'turtle-feast of the Sons of Satan.' This letter (no. 499), directed to John M'Murdo, describes the collection in less effusive, but no less important terms:

I think I once mentioned something to you of a Collection of Scots Songs I have for some years been making: I send you a perusal of what I have gathered. - I could not conveniently spare them above five or six days, \& five or six glances of them will probably more than suffice you. - When you are tired of them, please leave them with Mr. Clint of the King's Arms. - There is not another copy of the Collection in the world, \& I should be sorry that any unfortunate negligence should deprive me of what has cost me a good deal of pains. - (Letters 2:138)

After Burns's sentence about M'Murdo needing 'five or six glances' to satisfy his curiosity, Burns's first editor James Currie had interpolated a sentence of his own composition - 'A very few of them are my own' - into the letter. Roy remarks that Currie's dismissive sentence has led 'several generations of readers into the mistaken belief that Burns's

21 Even if the epigraph is not Burns's work, it is obviously inspired in spirit by such poems as 'Address to the Unco Guid' and 'Libel Summons.' 
disavowal was true' (xii), and J. DeLancey Fergusson, the co-editor with Roy of Burns's letters, also affirms that 'the sentence has often been used to show that most of the poems in the Merry Muses were not by Burns' (Letters 2:138). However, as James Kinsley usefully remarks, 'Burns does not here, however, claim any of the "Collection" as his own' (6).

Nevertheless, Kinsley concludes in the same article that 'my analysis suggests that of the fourteen songs surviving — or recorded as having survived - in holograph, eight [...] support the view that the compiler of the Muses worked from Burns's "fair" papers or from reasonably faithful copies' (20). ${ }^{22}$ Likewise, Roy finds that'twelve of the songs which appear in The Merry Muses exist in the poet's hand, and there are another nine among the assembled poems which were collected but not written by him' (xvii). Both conclusions affirm not only the very real possibility that the Merry Muses was in fact compiled from Burns's 'Collection,' at least in a rough state, but also establish Burns's authorship of certain texts. ${ }^{23}$

Furthermore, such conclusions suggest that the Fencibles played a part in the creation of the book by supplying its compiler with copies of bawdy verse that Burns had distributed to club members. If this was indeed the case (and it seems the most probable), then the Merry Muses certainly has to be regarded as club poetry, even if a club member (rather than Burns himself) compiled the volume. Even if Burns had intended the collection to have a limited distribution, its secrecy as a whole does not necessarily imply that he did not write or collect bawdry without an audience in mind. Along with the references to his collection I have mentioned in his letters, he sent a number of bawdy verses to fellow Fencibles such as Alexander Cunningham and Robert Cleghorn, as well as his good friend at the time, Robert Ainslie.

22 Postulating the existence then of a "heterogeneous "Collection" of bawdy papers "under lock and key in Dumfries" in the 1790s' (20), Kinsley offers a plausible explanation for its appearance in print as the Merry Muses. He suggests that Peter Hill, a clerk in the shop of Burns's publisher Creech, may have relayed a copy of Burns's 'Collection' to Andrew Erskine, which thus found its way to publication. Kinsley explains that 'in January 1793 Andrew Erskine asked Burns for a copy of his "Collection", naming Hill as a go-between for payment. Later in the same month Burns, in a letter to Thomson, sent his compliments to Erskine and promised that "he shall hear from me and receive his M.S.S. soon". It is probable [...] that a copy of the "Collection" went to Hill; and that, for publication [...] it was supplemented from other holograph versions - and from other poems or collections of poems current among the Crochallan Fencibles' (20-21).

23 In my use of the Merry Muses, though I refer to Roy's facsimile edition, I discuss only those poems that Kinsley has confirmed as Burns's work. 
Such poems would have appealed to the broad tastes of the Fencibles, especially its founder Smellie, the 'old Veteran in Genius, Wit, and Bawdry.' The verses' explicit nature also would have contributed to their underground circulation among friends of the poet. ${ }^{24}$ The same case was true of other poems and songs by Burns, particularly religious satires like 'Holy Willie's Prayer' which Burns copied several times after its composition to satisfy friends' demands. ${ }^{25}$ Burns was also very generous about sharing his work in various stages of completion with a number of his friends and correspondents, often altering or omitting poems from his collections on their good (or bad) advice. ${ }^{26}$ His attitudes in this regard support the view that due to Burns's generosity in distributing his work, several Fencibles would have been familiar with the poems and songs that eventually were published as the 1799 Merry Muses.

It has been essential to establish this because the legitimacy of the Merry Muses in Burns's oeuvre has been contested from the moment of its appearance. It has been variously castigated for its vulgarity or seen as simply coarse specimens of a Scottish folk tradition of bawdry that do not represent the poet at his best, in either collecting or composition. There is some truth in both views, in that the poems and songs in the Merry Muses are undeniably frank and bawdy and also that as a whole, they are not even close to the measure of his best work. The poems and songs in the collection that can be positively attributed to Burns exhibit the same kind of reductive simplification and exaggeration as that seen in his folk sources, as well as very little of the conscious crafting and retooling he put into his alterations to traditional songs for James Johnson's or George Thomson's projects.

Likewise, the Merry Muses portrays the poet's attitudes about sex in a generally unflattering light, hence its notoriety in the Burns canon. A typical speaker in the Muses extols the virtues of a fiercely male sexuality, given expression usually through phallic dimensions. Women's sexual-

24 The underground circulation of bawdy or pornographic verse is of course nothing strange; Roy reminds us that 'as in every other literature, the Scots had a long tradition of bawdy poetry, much of it passed in the oral tradition as song' (vii). This is certainly true in Burns's case with the Fencibles, though the publication and distribution of The Merry Muses is an important exception.

25 Mackay discusses the manuscript circulation of Burns's poems in some detail (see 161 and 171).

26 The best-known poetic criticism from Burns's correspondents comes from Hugh Blair and Frances Dunlop; see chapter 5, 'The Sentimental Critics' (59-69) of Carol McGuirk's Robert Burns and the Sentimental Era for other examples. 
ity in the collection is likewise represented through a genital fixation, depicted as the source and center of male and female sexual pleasure. Inasmuch as there is any attempt at characterization, it is revealed as a series of phalluses and vaginas engaged in defiant intercourse.

Burns's verse in the Merry Muses also focuses on the sexual encounter as a moment of intense pleasure to be enjoyed without nodding to consequence. In this it is obviously not unusual (this aspect being a requisite trait not only of bawdry but of pornography), but it signals a drastic shift from the concept of the 'fornicator's honor' elaborated in 'Libel Summons.' However, the aggressive sexual representations in the Merry Muses were not without their counterpart in Burns's own reckless sexual activity from 1785 to 1788 . Given the rather thoughtless and irresponsible quality of bawdry in this respect, one might conclude that ultimately it has a damaging representational function in its normalizing of a rigidly masculinist sexuality.

Clearly a case can be made along these lines, and such a critique could make a powerful indictment of the reification of gender roles that occurs in much bawdry, Burns's included. However, as Robert Crawford notes,

appreciating how much Burns's work is informed by the vernacular club-world of masculinity in which [...] he was so at home, is an essential task for a modern audience. To view Burns in this light is to make possible important recalibrations of our understanding of the cultural authority of his poetry, and of his wider legacy ("Robert Fergusson's Robert Burns" 14-15).

If we regard Burns's work in the Merry Muses as an expression of this 'vernacular club-world of masculinity,' then it is useful to examine how Burns's bawdry also contributes to the representation of Scottish character seen in his other club poetry.

Burns extended and modified the representations of national character seen in his poetry for the Court of Equity by drawing on folk resources and his own celebrity as a unifying means in the Merry Muses. As a whole, however, the Merry Muses is as much a hodge-podge as one would expect. The 1799 edition contains eighty-six poems and songs, coinciding only in sexual subject matter, with little else in the way of style or form unifying them as a collection of work. No doubt this heterogeneity is largely a result of the random nature of the collection itself. This is not necessarily a weak point, however, since its miscellaneous character, coupled with a consistently masculinist perspective, likely broadened its appeal to varied male audiences.

This is evidenced in the satirical song 'I'll tell you a tale of a wife' (no. 277, printed in the Merry Muses as 'The Case of Conscience'), where the speaker begins his 'tale of a wife' whose life was 'fash' $d$ ' (vexed) by her 
sexuality, just by virtue of having natural sexual desires: 'I'll tell you a tale of a Wife,/And she was a Whig and a Saunt;/She liv'd a most sanctify'd life,/But whyles she was fash'd wi' her _-_- - (Burns, Poems and Songs 1:496-98, 1-4). ${ }^{27}$ The speaker expands on the wife's troubles by setting up a confessional scenario where she narrates her tale to a priest: 'Poor woman! She gaed to the Priest,/And till him she made her complaint;/"There's naething that troubles my breast/'Sae sair as the sins o' my _-." - ' (5-8). Her confession and the priest's absolution convey a type of religious satire similar to that seen in works like 'Holy Willie' and 'Address to the Unco Guid,' albeit in a much more explicit fashion. ${ }^{28}$ ' $\mathrm{I}$ 'll tell you a tale' offers a view of sexual desire and activity that directly counters the Kirk's punitive perspectives on the subject satirized in 'Libel Summons.'

Other examples of bawdry in the Merry Muses are the songs '[Bonie Mary]' (no. 435) and 'Act Sederunt of the Session - A Scots Ballad -' (no. 436). ${ }^{29}$ In 'Bonie Mary,' the subject turns from religious impediments which prevent sexual enjoyment to a more presumably 'natural' one, the overgrowth of the woman's pubic hair described in the song's chorus: 'Come cowe me, minnie, come cowe me;/Come cowe me, minnie, come cowe me; / The hair o' my a- is grown into my c_t, / And they canna win to, to m-we me' (Burns, Poems and Songs 2:717-18, 1-4). Similar imagery of pubic hair is not uncommon in Scots bawdry, ${ }^{30}$ but the speaker in this song dwells less on this anomaly than on the successful 'mowing' of the woman by 'wanton Wattie.' 'Act Sederunt of the Session' is a compressed legal satire in the vein of'Libel Summons,' where the fornicators no longer adjudicate but find themselves at the mercy of a stern law decreed by the Edinburgh Court of Session: 'In Edinburgh

27 My citations of the Merry Muses will be to Kinsley's edition.

28 Unsurprisingly, the priest absolves the wife by addressing her sexual complaint himself.

29 Both poems were sent in a letter (no. 592) dated October 25, 1793? (see Letters 2:255 for the questionable dating of the letter) to Burns's friend Robert Cleghorn, as well as appearing in the 1799 Merry Muses. In his letter, Burns recounts the process of composing the 'baudy-songs' that he has enclosed: 'From my late hours last night, \& the dripping fogs \& damn'd east-wind of this stupid day, I have left me as little soul as an oyster.-' 'Sir John, you are so fretful, you cannot live long.' - 'Why, there is it! Come, sing me a BAUDY-SONG to make me merry!!!-_' (Letters 2:255). See Burns, Poems and Songs 3:1446-47 for Kinsley's discussion of these works.

30 See Burns, Poems and Songs 3:1446-47. Kinsley lists such examples as 'Green Grow the Rashes,' 'Had I the Wyte,' 'The Ploughman,' and 'There's Hair on't.' 
town they've made a law,/In Edinburgh at the Court o' Session,/That standing pr-cks are fauteors a',/And guilty of a high transgression' (Burns, Poems and Songs 2:718-19, 1-4).

The political element of Burns's bawdry glimpsed briefly in 'Act Sederunt of the Session' becomes more pronounced in his song, '[Why should na poor folk mowe]' (no. 395). This song had been composed with a definite purpose in mind as well as a quite specific topical context, as Burns explained in a letter (no. 530) to Robert Graham of Fintry on January 5, 1792. In that letter, Burns desperately sought to convince Graham, who was a Commissioner of the Scottish Board of Excise, that 'the charges which Malice \& Misrepresentation have brought against me' (Burns, Letters 2:173) were false. These charges concerned foremost his purported advocacy for French revolutionary causes and ideals and his loyalty to the Hanoverian crown. The Board of Excise had been requested to look into Burns's political behavior in order to determine if he was 'disaffected to Government. ${ }^{, 31}$

The interesting feature of this incident is that Burns attempted to acquit himself of these charges by means of his song, 'Why should na poor folk mowe.' Despite its convivial origins and bawdy content, the song has its place among Burns's political writings according to the poet, revealing in his mind the true extent of his conduct during an incendiary time. He describes the song to Graham as

A tippling Ballad which I made on the Prince of Brunswick's breaking up his camp, \& sung one convivial evening [...] [that] I shall likewise send you, sealed up, as it is not every body's reading. - This last is not worth your perusal; but lest Mrs FAME should, as she has already done, use, \& even abuse, her old priviledge [sic] of lying, you shall be the master of every thing, le pour et le contre, of my political writings and conduct. (Burns, Letters 2:174-75)

Though he claims the song is 'not worth' Graham's perusal, Burns clearly felt that it could contribute towards vindicating him of charges that could have cost him his dearly bought post at the Excise. While the song itself most likely did not contribute to Burns's success in

31 The charges were communicated anonymously to the Board of Excise and resulted from Burns's conduct during a performance of 'As You Like It' in Dumfries in October 1792. Mackay states that Burns was 'alleged to have remained seated with his hat on during the playing of the national anthem, and to have joined in the clamour for "ça ira", the French Republican song' (519). See Mackay 519-524 for a detailed account of the whole affair. 
refuting the charges, ${ }^{32}$ it does reflect his political opinions in a markedly unconventional way. Whereas in the songs previously discussed in the Merry Muses the focus is generally on the physical exploits of male characters with no particular political context, in this song the act of 'mowing' (copulation) itself has a political edge, leveling classes as the common pursuit of princes, prelates, and poor folk alike.

'Why should na poor folk mowe' begins with an initial stanza followed by the chorus, both of which represent 'mowing' in terms of deprivation, an act turned to for the comfort of 'poor bodies' who have nothing else in their possession:

WHEN Princes and Prelates and het-headed zealots

All Europe hae set in a lowe,

The poor man lies down, nor envies a crown,

And comforts himsel with a mowe.-

And why shouldna poor folk mowe, mowe, mowe,

And why shouldna poor folk mowe:

The great folk hae siller, and houses and lands,

Poor bodies hae naething but mowe.-

(Burns, Poems and Songs 2:668-69, 1-8) ${ }^{33}$

As Kinsley points out, the sentiment in these lines is quite common (Burns, Poems and Songs 3:1416-17), without any directly political character other than the speaker's class affiliation with the 'poor folk' of the chorus. Burns politicizes the sentiment in the following stanzas by

32 Mackay calls the whole incident 'a storm in a teacup which Robert, with his propensity for self-dramatisation, had greatly magnified and distorted out of all proportion' (521). Despite Burns's exaggeration of its import, the Board's enquiry was officially completed with a rather stern lecture delivered to Burns from a Mr. Corbet, a Supervisor General: 'Robert was suitably cowed by his interview with Corbet. What passed between them was not tantamount to an "admonishment" in Excise parlance, but there is no doubt that Robert was given a verbal caution to behave in the future' (Mackay 526).

33 Kinsley describes the differences between the manuscript and Merry Muses versions of this song: the Merry Muses version 'differs little from that of the MSS in stanzas which are common; but it omits the final stanza, wishing marital delight to George III and Charlotte, and adds two others. The omission may be the printer's responsibility' (Poems and Songs 3:1417). I have followed Kinsley's version, particularly in the case of the final stanza, which very likely would have been known to the Fencibles as it had been included in the version sent in a letter (no. 527) on December 12, 1792 to Robert Cleghorn. 
advising 'great folk' like the princes, prelates, and zealots of the first line not only to enjoy a 'mowe' like the 'poor folk' but to abandon their political designs in favor of 'mowing.'

The second stanza argues that the Duke of Brunswick would have best remained at home with his 'Princess' than have waged his unsuccessful campaign against Dumouriez: 'When Br-nsw-ck's great Prince cam a cruising to Fr-nce/Republican billies to cowe,/Bauld Br-nsw-c's great Prince wad hae shawn better sense,/ At hame with his Princess to mowe' (9-12). There is an implicit political criticism in these lines, albeit one couched in great irony. The speaker avers with the knowledge of hindsight that Brunswick really would have been better suited 'mowing' at home. The topicality of the battle (Dumouriez having defeated Brunswick's forces on September 20,1792) ensured that Burns's readers in the Fencibles as well as Graham would have been familiar with the targets of Burns's satire, extended to include in the next stanzas the Duke of York, Frederick William II of Prussia, and Catherine II.

The song's jocular tone takes on a more aggressively sexual character in the next stanza, where the speaker relates a gruesome wish for Catherine II to get 'mowed' by the devil himself for her political designs: 'Auld Kate laid her claws on poor Stanislaus, / And Poland has bent like a bow:/May the deil in her a- ram a huge pr-ck o' brass!/ And damn her in h-ll with a mowe!' (21-24). Though Kinsley claims that 'Burns's wish for Catherine is appropriate ... [for] her immorality was notorious, and the subject of British caricature' (Burns, Poems and Songs 3:1418), the representation of 'mowing' in these lines appears more violent than satiric in its immediate intent. In few other pieces of Burns's bawdry is the sexual act depicted with such a forceful, excessively masculinist perspective than in these lines. Though Burns may have had a legitimate political complaint with Catherine II's decision to subject Poland to a second partition in 1793 after a quashed independence movement, his infernal punishment for her seems designed less by Dante than the Marquis de Sade.

The poem's final stanza returns to its convivial origins, exhorting readers to share a bumper with the speaker and toast the 'mowing' of their own king and queen: 'But truce with commotions and new-fangled notions,/ A bumper I trust you'll allow:/Here's George our gude king and Charlotte his queen,/ And lang may they tak a gude mowe!' (25-28). Of the song's six stanzas, this last is most likely the one that Burns believed could help to extricate him from the charges being investigated by the Excise Board; it is at least the only one that treats British politics with what might be construed as a loyalist viewpoint. Toasting the royal couple implies a measure of respect for the institution of the monarchy, but certainly the stanza's last line could be in no way called 
respectful. ${ }^{34}$ The speaker's wish for George III and Charlotte is obviously better intentioned than his one for Catherine II, but it also has the effect of placing them on the same plane as the rest of the political rulers and the 'poor folk' whose 'mowing' forms the song's refrain.

This is a chief source of the difficulty in seeing 'Why should na poor folk mowe' as evidence of Burns's loyalism to the British monarchy. Since the song represents George III as a fornicator like everyone else (including poor folk), he is subject to the same foibles and ineffectual politics as his confreres on the Continent. Insofar as the song advances a political position, it advocates a democracy based on 'mowing' that would eliminate social divisions like the revolutionary ideals of brotherhood and classless equality. In this sense, 'Why should na poor folk mowe' is closer in spirit to the seditious principles that Burns felt the song positively disavowed to his accusers. Such declarations held obvious meaning for known fornicators like Burns, but they also underscore the general thrust of Burns's club poetry for the Court of Equity and the Fencibles. In Burns's mind, the social and cultural climate sustained by the Kirk and Unionist politics encouraged the control of reprobates like himself, regardless of his bard status. The structures of feeling aligned with hegemonic belief systems like the Kirk did not represent the true or genuine character of the Scot.

According to Burns, such a representation of national character would have to account for sexuality in all its excess. If the value of a bard's poetry lay in its expression of national character through the poet's own self-definition and self-exposure, Burns's work in the Merry Muses has to be seen as aggressively counter-hegemonic in its sexual representations. Robert Crawford reminds us that 'what we know about the Fencibles shows that they celebrated not simply conviviality but also maleness and masculinity' ('Robert Fergusson's Robert Burns' 13). In this 'vernacular club-world of masculinity' where Burns's club poetry found its audience, Burns represents the masculine character chiefly by asserting fornication's fundamental importance as well as its class-defying impact on all fornicators in the nation, unifying Scots and all folks rich, poor, untitled, even royal.

34 Certainly the King's uxoriousness was a target of satirists, of which Burns is no exception here, and the royal couple's seven sons and six daughters still living at the date of the song are testament to their enjoyment of a 'mowe.' Also, their appearance in the song is fitting due to the family relation with the Duke of Brunswick, Charlotte's brother. However, the final stanza's satiric intention is still striking in a poem that is avowedly political in its intentions. 
In this gesture, Burns affirms one of the key elements of bawdry's appeal to readers but more significantly, he validates an alternative selective tradition in his country's culture (folk bawdry) that remains a source of contention. As in his song collecting for Thomson and Johnson, Burns preserves and revises folk materials in the Merry Muses in order to keep the existing oral remnants intact and to proffer his own contributions to a genre that he found meaningful. Along with the other cultural work that Burns did along these lines, the Merry Muses represents his 'bardic' voice at its most oppositional, deployed in an effort to contest structures of feeling that he felt were unfair and absurd.

Though the collection has little in the way of overt political content, it has oppositional political qualities due to its counter-hegemonic impulse as well as its disputed status in Burns's canon. Burns realized quite early that he could use his fame as a means of unifying readers, and his club poetry served as the crucible for his experiments in this vein. Burns created an imagined national community through the vehicle of the self, employing representation as the means for unifying a national audience. This unification followed from the audience's identification with the bard, through whom they could envision a more heroic, nationalist, and sexualized version of themselves.

Burns's understanding of argument and folk culture allowed him to resist efforts by the literati to reify his self-presentation as a 'heaventaught ploughman,' and his desire to surpass hegemonic strictures in the name of 'genuine' character shows the degree to which his conventional sentimentalism could not contain his radical political energies. Though legions of Burns's 'bardolaters' from the nineteenth century on have attempted to obscure the poet's unseemly sexuality and politics in his verse and life, Burns's continuing appeal to readers the world over only confirms the success of his bardic self-exposure. He applied the ideal of the 'Honest Man' to himself as well as to others, and the national character in this representation derived in large part from his own experiences and observations, of which club life played no small part.

In clubs like the Court of Equity and the Fencibles, Burns assumed the bardic role and wrote to a national audience with a specific purpose in mind, aiming to unify the group by employing his celebrity and notoriety as tools for gauging and delimiting character. Burns's club poetry sought to reveal the true, genuine exposure of character that was necessary to bind people together in club, village or nation, and the open sexuality of his bawdry in the Merry Muses was as necessary an element of that character as the idealized traits represented in his love poetry and political songs. The value that Burns placed on the role of character in unifying his audience came out of his interest in sentimental discourse and also out of his own personal and sexual experiences. What distin- 
guishes his brand of sentimental nationalism is the degree to which his own self-representation, warts and all, became the index for the identification of his readers in club and nation alike.

\section{COREY ANDREWS}

Northwest Missouri State University

\section{Works Cited}

Burns, Robert. The Letters of Robert Burns. Ed. J. DeLancey Fergusson and G. Ross Roy. 2 vols. Oxford: Clarendon, 1985.

.The Merry Muses of Caledonia; A Collection of Favourite Scots Songs, Ancient and Modern; Selected for the Use of the Crochallan Fencibles. 1799. Fascim. ed. Columbia: University of South Carolina Press, 1999.

.The Poems and Songs of Robert Burns. Ed. James Kinsley. 3 vols. Oxford: Clarendon, 1968.

.The Works of Robert Burns. Ed. James Currie. Philadelphia, 1835.

Carswell, Catherine. The Life of Robert Burns. 1930. Edinburgh: Canongate, 1990.

Colley, Linda. Britons: Forging the Nation, 1707-1837. New Haven: Yale University Press, 1992.

Crawford, Robert. Devolving English Literature. $2^{\text {nd }}$ ed. Edinburgh: Edinburgh University Press, 2000.

.'Robert Fergusson's Robert Burns.' Crawford, Robert Burns 1-22.

Crawford, Thomas. Burns: A Study of the Poems and Songs. 1960. Edinburgh: Canongate Academic, 1994.

Daiches, David. Robert Burns: The Poet. 1950. Edinburgh: Saltire Society, 1994.

Kinsley, James. 'Burns and the Merry Muses.' Renaissance and Modern Studies 9 (1965): 521.

Mackay, James. RB: A Biography of Robert Burns. Edinburgh: Mainstream Publishing, 1992.

Mackenzie, Henry. The Man of Feeling. Ed. Brian Vickers. London: Oxford University Press, 1967.

McElroy, Davis. Scotland's Age of Improvement: A Survey of Eighteenth-Century Literary Clubs and Societies. [Pullman, WA]: Washington State University Press, 1969.

McGuirk, Carol. Robert Burns and the Sentimental Era. Athens: University of Georgia Press, 1985.

Roy, G. Ross. 'Robert Burns and The Merry Muses.' Burns, Merry Muses iii-xx.

Sterne, Laurence. A Sentimental Journey. Ed. Ian Jack. Oxford: Oxford University Press, 1984. 


\section{Corey Andrews}

Taylor, Anya. Bacchus in Romantic England: Writers and Drink, 1780-1830. London: Macmillan, 1999.

Trumpener, Katie. Bardic Nationalism: The Romantic Novel and the British Empire. Princeton: Princeton University Press, 1997. 